\title{
Econometric Modelling of the Variations of Norway's Export Trade across Continents and over Time: The Two-Stage Non-Full Rank Hierarchical Linear Econometric Model Approach
}

\author{
Yohannes Yebabe Tesfay and Per Bjarte Solibakke \\ Molde University College, Britveien 2, Kvam, 6402 Molde, Norway \\ Correspondence should be addressed to Yohannes Yebabe Tesfay; yohannesyebabe@gmail.com
}

Received 9 April 2015; Accepted 22 July 2015

Academic Editor: Udo Broll

Copyright (C) 2015 Y. Y. Tesfay and P. B. Solibakke. This is an open access article distributed under the Creative Commons Attribution License, which permits unrestricted use, distribution, and reproduction in any medium, provided the original work is properly cited.

\begin{abstract}
This paper applies the two-stage hierarchical non-full rank linear econometric model to make a deep analysis based on revenue generated from key Norwegian export items over the world's continents. The model's ability to analyse the variation of Norway's export trade gives us the following interesting details: (1) for each continent intra- and intervariation of export items, (2) access to deep knowledge about the characteristics of the Norway's export items revenue, (3) quantifying the economic importance and sustainability of export items within continents; and finally (4) comparing a given export item economic importance across continents. The results suggest the following important policy implications for Norway. First, Europe is the most important trade partner for Norway. In fact, $81.5 \%$ of Norwegian export items are transported to Europe. Second, there is a structural shift in Norwegian exports from North and Central America to Asia and Oceania. Third, the new importance of Asia and Oceania is also emphasized by the $85 \%$ increase in export revenues over the period 1988-2012. The trade pattern has changed and trade policy must change accordingly. The analysis has shown that in 2012 there are two important export continents for Norway: Europe and Asia and Oceania.
\end{abstract}

\section{Introduction}

In a global economy, there is no nation, which is autonomous to run its economy proficiently and meritoriously. In the absence of international trade, only hardly any nations could retain an ample standard of living. Any nation by means of only accessible domestic resources could only produce some degree of products, of course due to resource shortages. For example, a nation with an abundance of natural resources and another with skilled manpower, the crucial metamorphosis is to connect the nations on the international trade arena to share the benefits [1].

International trade is a vital component of the government's growth and prosperity agenda. Given the emphasis on facilitating international trade and increasing investment and exports, it is important to review recent international trade performance to understand patterns and adapt to future international trends. The recent global downturn has accelerated the shift in global market share towards emerging economies. This contraction is once in a lifetime event. The period covering the Great Depression and two world wars had a devastating impact on global trade. However, in the aftermath, there was a period of sixty successful years during which world goods trade almost constantly grew and fell in only eight of these years and never by more than $4 \%$. The world trade now looks set to return to growth far exceeding that of world GDP in 2011-2012. Each nation participates in the international trade for the purpose to sell what it produces, to acquire what it lacks of resources, and to produce efficiently and effectively in its existing advantageous economic industries. In most countries, international trade represents a significant share of gross domestic product (GDP). Ultimately, the international trade is transactions and give-and-take of goods and services across national boundaries. Precisely, we can therefore define international trade as the exchange of capital, goods, and services across 
international borders or territories. Import is defined as an inbound trade and export is defined as an outbound trade $[1,2]$.

Nations, as, for example, Norway, participate in international trade for two fundamental reasons. Firstly, the world's nation trade for the reason that their economic dependence and structure are poles apart. Consequently, individual nations can benefit from their differences by reaching arrangements in international trade through the exchange of goods and services in which nations produce the goods or service comparatively better. Secondly, economies of scale play a central role in the nation's international trade arena benefitting nations through reduction of production unit costs. That is, if each nation produces solitary some range of goods, it can produce each of these products on a larger scale and henceforward more efficiently than if it tried to produce all other goods. In the real world, international trade patterns reflect the combination and interaction of both economic dependence and economies of scale [3, 4].

Felbermayr and Kohler [5] present detailed evidence that the post-II-war increase of world trade took place through both larger traded quantities between countries (the country intensive margin) and an increase in the number of countries that engage in trade (the country extensive margin). Growth in trade is therefore driven by both extensive and intensive margin changes. Differences at the intensive margin generally contribute more to explaining trade patterns while distance and other nontariff barriers affect the extensive margin more strongly. The prediction made by Felbermayr and Kohler [5] is highly realistic and robust. In 2008, for example, the nations in the world as a whole produced goods and services worth about US $\$ 50$ trillion at present prices. About 32 percent (US\$16 trillion) of this overall world output was traded in the international market. Furthermore, international trade allows nations to trade a variety of resources, goods, and services from different geographical regions and continents. Therefore, international trade is a vigorous constituent to a government's growth policy and plans for affluence progress [6].

(1) The Problem. The main focus of this paper is unravelling the most important Norwegian export trade items over time and across continents. Analysis of these factors can shed light on how and why trade performance has differed and shifted and whether pre-2008 patterns in trade growth are likely to continue. Recent trade patterns globally include a global shift of goods market share towards emerging economies, a rapid increase in intermediate goods trade, a shift in developed economies' exports towards advanced manufacturing and services, and increasing demand for differentiated products among the middle classes of emerging economies.

The Norwegian export numbers have continued to climb in recent years. Figure 1 shows the Norwegian total export for the period 1988-2012. Export to Europe is on the right axes and export to other continents is on the left axes. By studying the axis numbers, the figure shows that export from Norway to the European continent distances significant other continents. Moreover, Norwegian export has shown a slow but constant growth with the exception of North and Central

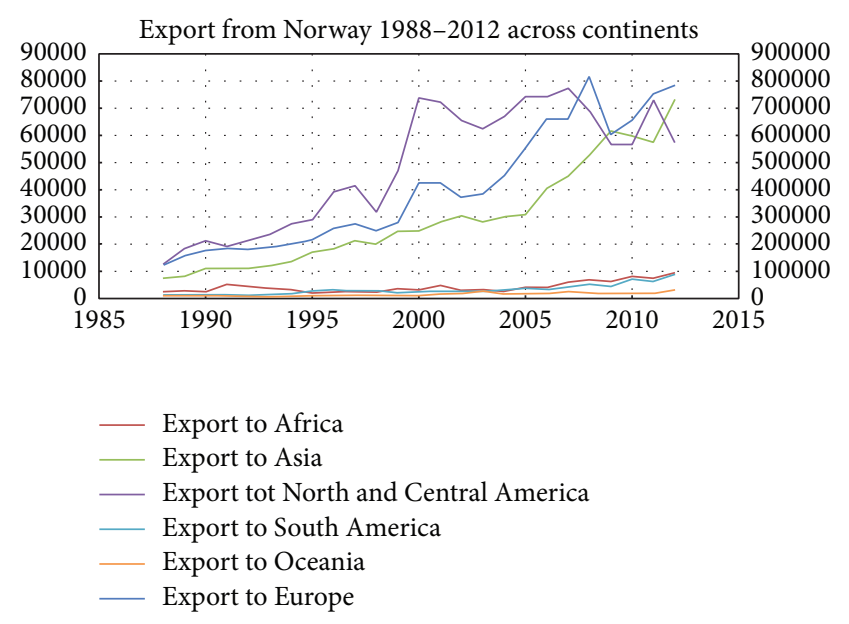

FIgURE 1: Total Norwegian Export during 1988-2012 across continents.

America from about the year 2000. Norwegian export is showing a steady increase from 1988 until today with some reduction during the financial crisis in 2009 and 2010 for all continents. The remaining three other continents report smaller export revenue. However, South America has shown rapid growth in recent years. Importantly, a market share loss of most advanced economies is due to the increase in export from emerging and newly industrialised economies. China's world export share, for instance, has increased by $500 \%$ since 1990 to $9,6 \%$ in 2009, overtaking Germany to become the largest goods exporter.

This paper focuses on trade pattern, structural changes, and overall continental variation of the Norwegian export trade across continents. The main objective of the study is to build econometric models that can show and give quantitative information about the variation of the Norwegian export trade based on the revenue obtained from export items across continents. Specifically, the paper tries to give solution for the following: (1) to assess whether the average revenue earned from the export sector of the country is consistent; (2) to assess whether continental or export item effects exist on the revenue earned from the export sector or not; (3) to analyse intracontinental characteristics of the export trade with respect to the importance of the item of export and its short and long run contribution to the Norwegian export sector; and finally (4) to analyse intercontinental comparisons of the destination continents of important Norwegian export items. However, in order to acquire this information for the continental variation of the Norwegian export trade we need to introduce an extended and powerful econometric model.

In the international trade, gravity model is a famous model to give econometric explanations of the determinant of bilateral trade. The model is built on the axel of the philosophy of the Newton gravitational equation and uses variables such as gross domestic product (GDP), gross national product (GNP) per capita, population size, colony, bilateral exchange rate, common currency, distance between capital cities, common language, and membership of a trading partnership to identify determinants. For example, the negative "gravity" 
relationship between trade and distance is driven almost entirely by the extensive margin. That is, both the number of trading firms and the number of traded products decline significantly with distance. Moreover, most studies find a strong response to the extensive margin to changes in trade barriers or country size [7, 8]. Employing the gravity model for such study has a number of limitations. First, in time series trade data factors like structural change, price volatility, and changes in demand (substitutes) are important for a nation's import trade. The gravity model will ignore these factors. Second, the gravity model hypothesized that the strength of the bilateral trade is negatively correlated with the distance between the capital cities of the trading partners. However, the model ignores the fluctuation of transportation cost that is negatively correlated with the geographical coverage of the flow of goods. Besides, the gravity model does not address the impact of the import/export item on the origindestination distance. For example, for a long period most of the production of oil in the world took place in the Middle East. Nevertheless, most of the oil and oil products are traded in the USA by traveling large distances. Third, the gravity model becomes illogical for the analysis of the import of high value to volume ratio products and low cost countries.

Moreover, in this context, the gravity model ignores an important aspect of the emergence of new competent importer and importer nations. For example, the emergence of China in the global economy made shifts of direction of the international trade. More importantly, the gravity model tried to identify the contributing factors of the bilateral trade between national trading partners. However, in the modern globalized world the economic dependence governs the bilateral trade between the nations. Fourth, the interpretation of the results from the gravity model for countries that have a high or low share in the international trade is similar. In this context the solution of the gravity model for how to characterize the strength of the import trade for a given nation is weak. Specifically, the solution of the gravity model will push us taken together prediction about the import sector of the given nation. Hence, there will be a lot of hidden trade information. It is the characteristics of strong nations that, in order to be competent and consequently improve their shares in the international trade, each nation has its own internal assignment of origin and destination. Among the internal assignments, it is vital to identify the characteristics of the generated import trade expenditures [9-15]. Furthermore, economists of international trade use descriptive statistical analysis to see the import and export of the given nation [16]. However, the use of statistical analysis is limited to the prediction of the short and the long run imports and exports trade patterns of a given nation [17]. Time series econometric models are good for forecasting [18]. However, the forecasting powers of time series econometric models are limited if structural breaks can randomly occur [19-21].

In order to have a structural insight of the variation of the export trade we make a thorough analysis applying the revenue generated from the different items of export (category of similar items) and its destination (country or continent wise). In order to meet our objective, we introduce the non-full rank hierarchical model, which is able to extend our understanding of the problems at hand from the available data series. The model analyses thoroughly the variation of the Norwegian export trade. The advantages are as follows: Firstly, the model allows us to determine the intra- and intervariation of the Norwegian export items across its destination. Secondly, the model enables precise estimators by providing large degrees of freedom to the export items. Moreover, the model contains information about the characteristics of the export items revenue enabling, thirdly, the quantification of the sustainability of the export and the economic importance of the nested factors in a given nesting factor; and finally, fourthly, the model enables us to compare a given nested factor across different nesting factors [22-26].

The economics of the international trade can be classified into two broad subfields: the analysis of international trade and the analysis international money. International trade exploration and analysis are primarily the real transactions in the international economy. The field of international trade concentrates therefore on those transactions that encompass a physical movement of goods or a tangible commitment of economic resources. The international monetary analysis focuses on the monetary side of the international economy, that is, on fiscal transactions such as foreign purchases, exchange rates, and other related issues [27, 28]. Our study is in the field of international trade and extracts rigorous information from the Norwegian export trade pattern.

\section{Literature Review}

2.1. Globalization and International Trade. The term globalization describes a process by which national and regional economies, the social order, and cultures have become assimilated through the global trade, communications, transportation, and immigration. Due to globalization in the last twenty years, the breadth and depth of links between nations and between regions have grown enormously [29]. The remuneration from globalization for developing nations is a faster catch-up to industrialized nations through increased employment and technological advances. Globalization causes nations to get a much wider diversity of products to choose from by a more competitive price, extensive markets, and the dropping of international barriers and obstacles by making trade unions. One positive side of globalization is disseminated knowledge and efficient usage of resources for the production of goods and services [30].

Globalization has numerous designations, depending on the subject being explained. For international economists it has a humble definition, notwithstanding one with powerful implications. Globalization occurs when the markets of different countries become more assimilated and interrelated through economic transactions that cross national borders. Economic globalization encompasses the globalization of competition of corporations and industries through technology, markets, and production [31]. The economic globalization is centered on the diminution of international trade regulations as well as prices, tariffs, duties, and other impediments that suppress global trade. International trade, therefore, is the real part of economic globalization that is 
concerned with the exchange of goods or services across national jurisdictions [32].

International trade has full-fledged enormously since World War II. The international trade from 1955 to 2005 in manufacturing goods alone has grown from $\$ 95$ billion to $\$ 12$ trillion. Because of the large amount of money traded on the globe, the participation of many countries has been increasing with time. The growth of international trade leads to intensifying completion among nations through technology and efficient utilization of resources [33].

International trade consequently makes evident the scope of globalization with improved spatial interdependencies concerning the fundamentals of the global economy and their degree of integration. These interdependencies point toward copious relationships where flows of goods, services, capital, and raw materials are established flanked by regions of the world. International trade is also a matter of considerable contention among the different components of the nation. Hence, the nation's participation in the international trade at a time is a troublemaking social and economic strength as it vicissitudes the state of affairs in which prosperity is disseminated within a national economy. This is predominantly due to ups and downs in prices and wages [34].

The participation of nations, the amount of the transaction, and variety of trading goods and services are increasing with time; hence international trade played important role in developing the global economy. Therefore, we give attention to the theoretical approaches and analysis of how international trade benefits each nation across the globe. A rich body of international trade theory helps explaining patterns of trade at the industry level, taking account of industry and country differences in knowledge and technology [35].

According to David Ricardo, the comparative advantage international trade theory explained the benefit of trade using the concept of opportunity cost. Economists use the term opportunity cost to refer to such a compromise and tradeoffs of producing several goods. A nation has a comparative advantage in producing a good if the opportunity cost of producing that good in terms of other goods is lower in that nation than in other nations. The motivation that international trade produces this proliferation in world productivity is that it sanctions each nation to dedicate itself to and specialize in producing the product in which it has a comparative advantage. Therefore, the Ricardian model of developed international trade illustrates the potential benefits of trade as trade leads to international specialization, though all nations diverse its labor force commencing industries in which labor is comparatively inefficient to industries and in which it is reasonably more efficient [36].

The Heckscher-Ohlin model analysed international trade in a way that is more rigorous. The Ricardian model assumes that the only factor to be considered to analyse international trade was labor of production. This means that the Ricardian model assumes comparative advantage could get to your feet only because of international differences in labor productivity. However, in the real world, despite the fact that trade is partially enlightened by dissimilarities in labor productivity, it likewise more importantly imitates differences in nations' resources. Therefore, in convincing manner the Heckscher-Ohlin model explains the role of resource differences in trade while it is unnoticed by the Ricardian model [37].

The contribution of both the Ricardian and the Heckscher-Ohlin models suggests that in the international trade both import and export are equally important for the economic development and maximization of the welfare of the given nation.

2.2. Overview of Norway's Economy. Norway is richly endowed with natural resources, including petroleum, fish, forests, hydropower, and minerals. Norway's emergence as a major oil and gas producer in the mid-1970s transformed the economy. The Norwegian continental shelf's total recoverable petroleum resources have been estimated at 12.8 billion standard cubic meters of oil of which 5.5 billion has been recovered. Furthermore, Norway controls one of the largest ocean spaces in the world. Consequently, the primary economic activities include oil and gas, hydroelectricity, fish farming, and manufacturing [38].

The key industrial sectors of Norway are the strategic petroleum sector (Statoil and Aker Solutions), hydroelectric energy production (Statkraft), aluminium production (Norsk Hydro), the largest Norwegian bank (DnB NOR), and telecommunication provider (Telenor). Through these relatively large companies, the government controls more than $30 \%$ of the stock values at the Oslo Stock Exchange [39].

Because hydropower provides the highest share of Norway's electricity, most of the extracted gas and oil is exported. Today's export makes Norway one of the largest oil and gas exporters in the world. Norway provides much of Western Europe's crude oil and gas requirements. Norwegian oil and gas exports accounted for a large part of the country's total exports and contributed to a significant amount of the country's GDP [40].

Today Norway ranks one of the richest countries in the world. Next to Luxembourg, the country has the highest GDP per capita in the world. The average hourly wages in Norway are among the highest in the world. From 2001 to 2006, Norway continued first place in the world in the UNDP Human Development Index and then reclaimed this position in 2009 and 2010. Norway has a very low unemployment rate and the standard of living is among the highest in the world [41].

\section{The Norwegian Dataset and the Hierarchical Model}

3.1. The Norwegian External Trade Dataset. The dataset is from Statistics Norway (http://www.ssb.no/) and is downloaded from Statbank Norway (http://www.ssb.no/en/ statistikkbanken) and External Economy (external trade, external trade in goods, 08801). The data are organised yearly ranging from 1988 to the end of 2012 (25 years). The export items listed in these data from Statistics Norway may overlap. That is, the item export excluding ships and oil rigs may partly overlap mainland export. However, based on data from Statistics Norway, this is the closest we find individual 
TABLE 1: External trade in goods in million NOK.

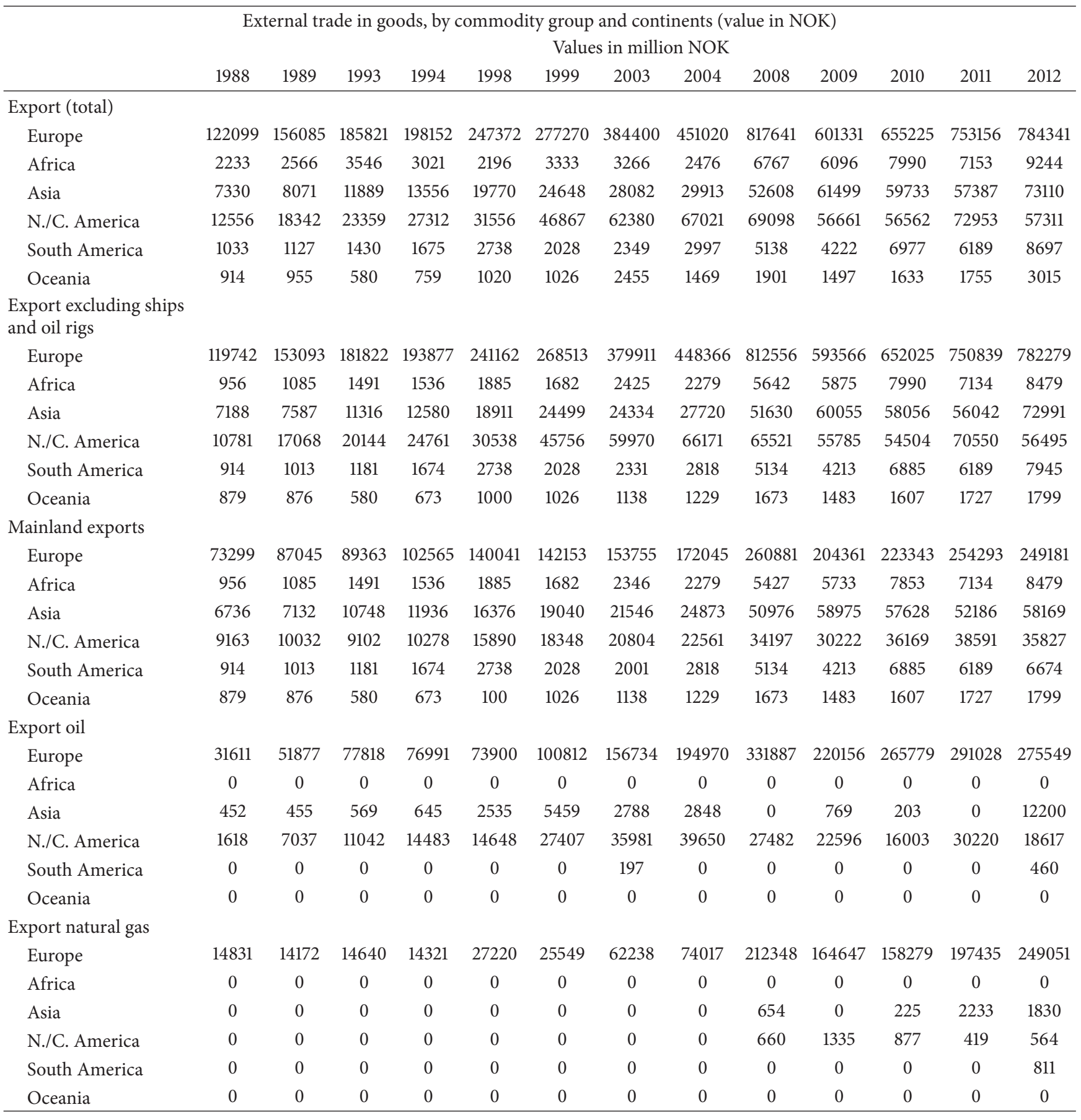

export items. The interpretations, however, from the model results interpret all export items as individual items without overlap. Table 1 shows a subsample of data for the Norwegian export numbers. Some of the years are not reported due to space considerations. The data are organised, suitable for the objectives set by the hierarchical model (see next section).

3.2. The Hierarchical Model: The Two-Way Nested Classifications. The two-way nested classifications are linear models having two independent factors in which one of the factors is nesting the other factor. More specifically, given two factors, $A$ and $B$, the levels of $B$ are said to be nested within the levels of A (or simply B is nested within A) if every level of B appears within each level of A [42, 43]. The model for nested classifications is given as [44]:

$$
y_{i j k}=\mu+\alpha_{i}+\beta_{j(i)}+\varepsilon_{i j k}
$$

where $i=1,2,3, \ldots, a$, is the level of the nesting factor, $j=1,2,3, \ldots, b$, is the level of the nested factor, and $k=$ $1,2,3, \ldots, n$, is the number of replications within each nested 
factor, $y_{i j k}$ is the observed value of the $k$ th cell from the $j$ th nested factor within the $i$ th nesting factor, $\mu$ is the grand mean of $y_{i j k}, \beta_{j(i)}$ is the $j$ th factor nested under the $i$ th nesting factor effects, $\alpha_{i}$ is the $i$ th nesting factor effects, and $\varepsilon_{i j k}$ is the random error term of the model.

This two-way nested classifications model allows us to compare a given nested factor across different nesting factors. The system of linear equations in matrix form is given as

$$
Y=X \gamma+\varepsilon
$$

where $X=\left[\begin{array}{lllll}L_{a} & \cdots & I_{a} \otimes L & \cdots & I_{a b} \otimes \ell\end{array}\right]$

$$
Y=\left[\begin{array}{c}
y_{111} \\
y_{112} \\
y_{113} \\
\vdots \\
y_{i j k} \\
\vdots \\
y_{a b n}
\end{array}\right]_{a b n \times 1}
$$
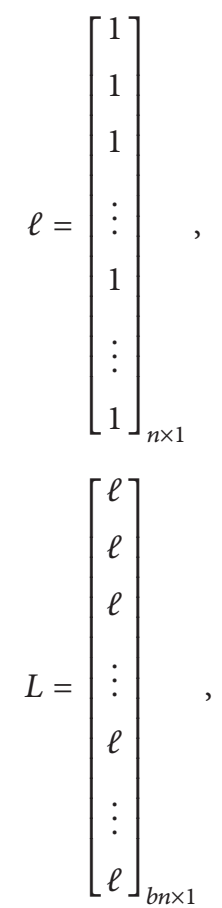

$$
L_{a}=\left[\begin{array}{c}
L \\
L \\
L \\
\vdots \\
L \\
\vdots \\
L
\end{array}\right]_{a b n \times 1}
$$

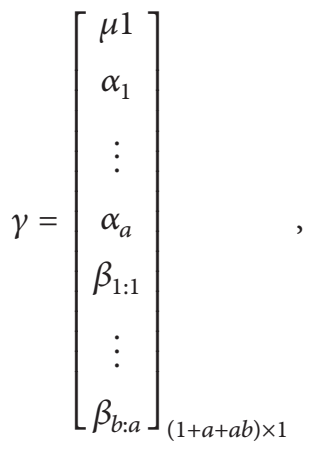

$$
\varepsilon=\left[\begin{array}{c}
\varepsilon_{111} \\
\varepsilon_{112} \\
\varepsilon_{113} \\
\vdots \\
\varepsilon_{i j k} \\
\vdots \\
\varepsilon_{a b n}
\end{array}\right]_{a b n \times 1}
$$

Let us compute the dimension and the rank of the $\mathrm{X}$ matrix:

(i) Rows of $X=$ Rows of $Y=a b n$.

(ii) Rank of $X \leq \min \{a b n, 1+a+a b\} \Rightarrow \operatorname{Rank}$ of $X \leq$ $1+a+a b \forall a, b, n \geq 2$.

From the $X$ matrix we see that $L_{a}$ is a linear combination of $I_{a} \otimes L$, and the columns of $I_{a} \otimes L$ are linear combinations of $I_{a b} \otimes \ell$. Consider

$$
\therefore \operatorname{Rank}[X]=\operatorname{Rank}\left[I_{a b} \otimes \ell\right]=a b .
$$

Hereafter our primary intention is whether we can estimate the model parameters or not. In order to reach a conclusion we need to see the characteristics of the normal equations [45]. We have

$$
\begin{aligned}
Y & =X \gamma+\varepsilon \\
& \Longrightarrow \varepsilon=Y-X \gamma \\
& \Longrightarrow \varepsilon^{\prime} \varepsilon=[Y-X \gamma]^{\prime}[Y-X \gamma] \\
& =Y^{\prime} Y-\gamma^{\prime} X^{\prime} Y-Y X \gamma+\gamma^{\prime} X^{\prime} X \gamma \\
& \Longrightarrow \frac{\partial \varepsilon^{\prime} \varepsilon}{\partial \gamma}=-2 X^{\prime} Y-Y X \gamma^{0}+2 X^{\prime} X \gamma^{0}=0
\end{aligned}
$$

Therefore, our normal equation is

$$
X^{\prime} X \gamma^{0}=X^{\prime} Y \text {. }
$$

Rank of $X^{\prime} X=$ Rnak of $X=a b<1+a+a b \forall a, b, n \geq$ 2. The result implies that we cannot estimate all the model parameters. Therefore, we need to advance our analytical methods. First, our goal is to find the standard error of the model using algebraic manipulations on the normal equations. Then, we generate estimable functions from the model and test our hypotheses. 
3.3. Model Overall Model Fit Using Generalized Inverse. From our normal equations we observe that Rank of $X^{\prime} X=a b$ and the dimension of $X^{\prime} X=1+a+a b$. We decompose $X^{\prime} X$ as follows $[46,47]$ :

$$
\begin{aligned}
& {\left[\begin{array}{ccc}
{\left[L_{a}\right]^{\prime}\left[L_{a}\right]} & {\left[L_{a}\right]^{\prime}\left[I_{a} \otimes L\right]} & {\left[L_{a}\right]^{\prime}\left[I_{b a} \otimes \ell\right]} \\
{\left[I_{a} \otimes L\right]^{\prime}\left[L_{a}\right]} & {\left[I_{a} \otimes L\right]^{\prime}\left[I_{a} \otimes L\right]} & {\left[I_{a} \otimes L\right]^{\prime}\left[I_{a b} \otimes \ell\right]} \\
{\left[I_{b a} \otimes \ell\right]^{\prime}\left[L_{a}\right]} & {\left[I_{a b} \otimes \ell\right]^{\prime}\left[I_{a} \otimes L\right]} & {\left[I_{a b} \otimes \ell\right]^{\prime}\left[I_{a b} \otimes \ell\right]}
\end{array}\right]\left[\begin{array}{c}
\mu^{0} \\
\sigma_{i}^{o} \\
\beta_{j(i)}
\end{array}\right]} \\
& =\left[\begin{array}{c}
\sum_{i=1}^{a} \sum_{j=1}^{b} \sum_{k=1}^{n} y_{i j k} \\
\sum_{j=1}^{b} \sum_{k=1}^{n} y_{i j k} \\
\sum_{k=1}^{n} y_{i j k}
\end{array}\right] .
\end{aligned}
$$

Another important property here that we need for our analysis is the Eigen value of the $\left[I_{a b} \otimes \ell\right]^{\prime}\left[I_{a b} \otimes \ell\right]$ matrix. Applying the rule of matrix multiplication, we have $\left[I_{a b} \otimes\right.$ $\ell]^{\prime}\left[I_{a b} \otimes \ell\right]=n I_{a b}$. Therefore, the Eigen value of $\left[I_{a b} \otimes \ell\right]^{\prime}\left[I_{a b} \otimes\right.$ $\ell]=$ the Eigen value of $n I_{a b}$. Using the definition of Eigen value [48], we have

$$
\begin{aligned}
\operatorname{det}\left|n I_{a b}-\lambda I_{a b}\right| & =0 \\
& \Longrightarrow \operatorname{det}\left|I_{a b}-(n-\lambda)\right|=0 \\
& \Longrightarrow(\lambda-n)^{a b}=0
\end{aligned}
$$

and therefore, $\lambda=n$.

Equation (8) tells us that the Eigen values of $\left[I_{a b} \otimes \ell\right]^{\prime}\left[I_{a b} \otimes \ell\right]$ are the sample size. This has extremely important contribution from the two-stage non-full rank nested classification for our econometric modelling. First, the sample size contributes to the precision of the estimates of the standard error of the model $[49,50]$. In addition, since the Eigen values of the information matrix of the model are equal to the sample size, by adjusting the sample size, we can see the characteristics of the model parameters and this will aid us to evaluate structural changes on the import trade of Norway. Second, the sample size " $n$ " is the expected value of the $n$-independently distributed chi-square values, which is the distribution of variance $[51,52]$. This directly shows that the information matrix of the two-stage non-full rank nested classification is the key to meet the objective that we already set.

In order to estimate the standard error of the model we first find at least one solution for our normal equations using the generalized inverse of $X^{\prime} X$. By definition $[44,53]$, a matrix $\left(X^{\prime} X\right)^{-}$is the generalized inverse of $X^{\prime} X$ if and only if

$$
\left(X^{\prime} X\right)\left(X^{\prime} X\right)^{-}\left(X^{\prime} X\right)=X^{\prime} X
$$

The rank of the matrix $X^{\prime} X$ is $a b$ (we have $a b$ orthogonal contrasts). Since the incidence matrix is not of full rank, there are infinitely many solutions to the normal equations. However, the regression sum of squares is invariant (unaffected) by the choice of one of the solutions [44]. Using the generalized inverse of $X^{\prime} X$ solves the normal equation. One of the generalized inverses is given as

$$
\left(X^{\prime} X\right)^{-}=\left[\begin{array}{cc}
0_{(a+1) x(a+1)} & 0_{(a+1) x(a b)} \\
0_{(a b) x(a+1)} & \left(\left[I_{a b} \otimes \ell\right]^{\prime}\left[I_{a b} \otimes \ell\right]\right)^{-1}
\end{array}\right] .
$$

Therefore, it is indispensable to apply the two-stage non-full rank nested classification for our econometric modelling to evaluate the overall variation of the import trade of Norway. The generalized inverse, which we set in (9), yields the following solution:

$$
\gamma^{0}=\left[0,0, \ldots, 0, \bar{y}_{11 .}, \bar{y}_{12 .}, \ldots, \bar{y}_{i j .}, \ldots, \bar{y}_{a b .}\right] .
$$

In order to make inferences to the two-way nested non-full rank model, we first find the sums of squares of interest, their degree of freedom, and respective probability distribution $[44,46,47]$. Table 2 gives the information.

3.4. Estimable Functions and Testing Hypothesis. In non-full rank linear models, we cannot estimate all model parameters, and consequently, we are at a loss to test every hypothesis of interest. In order to determine the testability of our hypotheses, we need to identify which linear functions are estimable functions. The concept of estimability of functions is important in the theory and applications of linear models because hypotheses of interest are often expressed as linear combinations of the parameter estimates. Estimable functions are functions that are exactly equal to a linear function of the expected values of the response variable $Y$. Mathematically a linear function $L \gamma$ is estimable if [44]:

$$
L \gamma=K E(Y) \text { for some matrix } K \text {. }
$$

Since $E(Y)=X \gamma$, the definition of estimability implies that $L \gamma$ is estimable if there exists a matrix $K$ such that $L=K X$. This directly implies that the rows of $X$ form a generating set from which all estimable functions can be constructed. Since estimability is not related to the particular value of a parameter estimate but to the row space of $X$, we can test only hypotheses that consist of estimable functions. Further, because estimability is not related to the value of $\gamma[44, \mathrm{p} .181]$, the choice of a generalized inverse in a situation with rankdeficient $X^{\prime} X$ matrix is immaterial, since

$$
L \widehat{\gamma}=K X \widehat{\gamma}=K X\left(X^{\prime} X\right)^{-} X^{\prime} Y,
$$

where $X\left(X^{\prime} X\right)^{-} X^{\prime}$ is invariant to the choice of a generalized inverse $\left(X^{\prime} X\right)^{-}$of $X^{\prime} X$.

$L \gamma$ is estimable if and only if $L\left(X^{\prime} X\right)^{-} X^{\prime} X=L$ (see, e.g., [44, p. 185]). If $X$ is full rank, the Hermite matrix $\left(X^{\prime} X\right)^{-} X^{\prime} X$ is the identity, which implies that all linear functions are estimable in the full rank case. In addition, linear combinations of estimable function are also estimable. Table 3 gives us the linear functions that are estimable in the two-way nested classifications [44, 46, 47].

3.5. Model Adequacy Checking. It is necessary to check the model, whether it fulfills the theoretical assumptions. The 


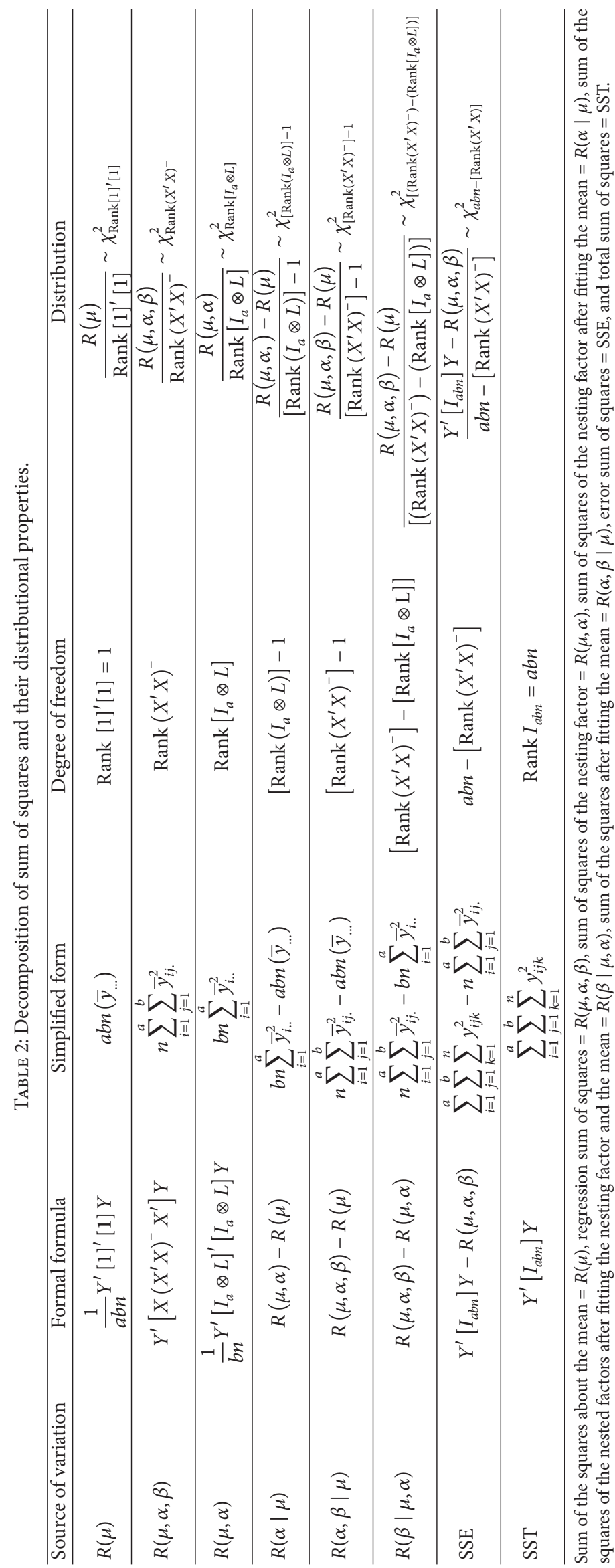


TABLE 3: Estimators of estimable functions in the two-way nested classifications.

\begin{tabular}{|c|c|c|c|c|}
\hline Estimable function & BLUE & DF & Variance of BLUE & $\begin{array}{l}F \text {-calculated and with probability } \\
\text { distributions of null hypothesis }\end{array}$ \\
\hline$\mu+\alpha_{i}+\beta_{j(i)}$ & $\bar{y}_{i j}$ & 1 & $\frac{\sigma^{2}}{n}$ & $\frac{n \bar{y}_{i j .}}{\mathrm{MSE}} \sim F_{\left[1, a b n-\operatorname{Rank}\left(X^{\prime} X\right)\right]}$ \\
\hline$\beta_{j(i)}-\beta_{j^{\prime}(i)}$ & $\bar{y}_{i j .}-\bar{y}_{i j^{\prime}}$ & 2 & $\frac{2 \sigma^{2}}{n}$ & $\frac{n\left(\bar{y}_{i j .}-\bar{y}_{i j^{\prime} .}\right)}{2 \mathrm{MSE}} \sim F_{\left[2, a b n-\operatorname{Rank}\left(X^{\prime} X\right)\right]}$ \\
\hline$\alpha_{i}-\alpha_{i^{\prime}}+\beta_{j(i)}-\beta_{j\left(i^{\prime}\right)}$ & $\bar{y}_{i j .}-\bar{y}_{i^{\prime} j}$ & 2 & $\frac{2 \sigma^{2}}{n}$ & $\frac{n\left(\bar{y}_{i j .}-\bar{y}_{i^{\prime} j .}\right)}{2 \mathrm{MSE}} \sim F_{\left[2, a b n-\operatorname{Rank}\left(X^{\prime} X\right)\right]}$ \\
\hline
\end{tabular}

entire model adequacy is done by analysis of the residuals $\left(\widehat{\varepsilon}_{i j k}=y_{i j k}-\widehat{y}_{i j k}\right)$. Generally, we have two basic categories, the data problems and the statistical problems. In particular, the data problems consist of the existence of outliers and the statistical problems consist of distribution assumptions, heteroscedasticity, and autocorrelation.

We can identify observations, which cause the outlier problems by transforming the residuals into studentized residuals and standardized residuals [54]. We can also test heteroscedasticity using the Bartlett's test [55]. The important sign and consequence of the existence of outliers and heteroscedasticity are quite similar. Both problems will reduce the coefficient of determination and increase the mean square errors. As a result, we find that important predictors might turn out to be insignificant. Therefore, we use a variance minimization of transformation to handle these problems (like the logarithmic transformation).

Whenever we use a time series data, we encounter the problem of autocorrelation. This problem leads to hiding (underestimate or overestimate) the variance of the random error term and increase the coefficient of determination. As a result, the model gives a false information to the researcher $[56,57]$. In this case, we randomize the observations to eliminate the time pattern of the observations before analysis. Alternatively, we use the raw data as it is and we use the Brewish-Godfrey test of autocorrelation [58]. After identifying the order of autocorrelation, we specify a reasonable model as

$$
y_{i j k}=\mu+\alpha_{i}+\beta_{j(i)}+\varepsilon_{i j k}
$$

where $\varepsilon_{i j k}=\rho_{i j} \varepsilon_{i j k-1}+v_{i j k},\left|\rho_{i j}\right|<1$, and $v_{i j k} \sim$ $i i D\left(0, \sigma_{v}^{2} I_{a b n-1}\right)$. Let us apply the Cochrane-Orcutt transformation [59] to eliminate the autocorrelation structure of the model:

$$
\rho_{i j} y_{i j k-1}=\rho_{i j} \mu+\rho_{i j} \alpha_{i}+\rho_{i j} \beta_{j(i)}+\rho_{i j} \varepsilon_{i j k-1}
$$

Subtract (15) from (14):

$$
\begin{aligned}
y_{i j k}-\rho_{i j} y_{i j k-1}= & \left(1-\rho_{i j}\right) \mu+\left(1-\rho_{i j}\right) \alpha_{i} \\
& +\left(1-\rho_{i j}\right) \beta_{j(i)}+\varepsilon_{i j k}-\rho_{i j} \varepsilon_{i j k-1}, \\
y_{i j k}-\rho_{i j} y_{i j k-1}= & \left(1-\rho_{i j}\right) \mu+\left(1-\rho_{i j}\right) \alpha_{i}
\end{aligned}
$$

$$
\begin{array}{r}
+\left(1-\rho_{i j}\right) \beta_{j(i)}+v_{i j k}, \\
y_{i j k}^{*}=\mu^{*}+\alpha_{i}^{*}+\beta_{j(i)}^{*}+v_{i j k},
\end{array}
$$

where $y_{i j k}^{*}=y_{i j k}-\rho_{i j} y_{i j k-1}, \mu^{*}=\left(1-\rho_{i j}\right) \mu, \alpha_{i}^{*}=(1-$ $\left.\rho_{i j}\right) \alpha_{i}$, and $\beta_{j(i)}^{*}=+\left(1-\rho_{i j}\right) \beta_{j(i)}$. Equation (16) suggests that the problem of autocorrelation is eliminated due to the Cochrane-Orcutt transformation. We are going to fit the model by repeating from (2) to (13) recessively until the problem of autocorrelation is eliminated at any order.

\section{Empirical Results}

4.1. Fit of the Two-Stage Non-Full Rank Linear Nested Model. Before making further econometric analysis and elucidation about the continental variation of the Norwegian exports, we have to check whether the two-stage non-full rank linear nested model is suitable. The technique of analysis is made up of two factors. These factors are the continental categories (the nesting factor) and the export items (the nested factor). The observations are the revenue from exports (in 100 million of Norwegian Kroner). The domino effects of the model adequacy test indicate that our structure of econometric analysis is properly set. The fit of the model in Table 3 suggests that the Norwegian export trade shows heterogeneity either from the destination continent or the item of export.

As can be seen from Table 3, the F-statistic is significant. Consequently, the two-stage nested non-full rank linear model adequately describes the total variation of the Norwegian export trade across continents. Now, we need to see whether the continental and item effects are significant. The results of these tests are given in Table 4 .

From Table 4 we observe firstly that the average revenue $(R(\mu))$ netted from the export sector of Norway is increasing over time. Secondly, the items and the continental effect corrected for the mean $R(\beta, \alpha: \mu)$ are statistically significant. The implication is that at least one of the continental categories and/or export items does have a significant impact over the others on the overall Norwegian export trade. Third, the effects of item corrected for the continental effects and mean $R(\beta: \alpha, \mu)$ are statistically significant. This result indicates that at least one of the export items significantly contributes to the others on export trade of Norway controlling for the continental effects (or adjusting for the effects of the destination continent). The result indicates that the export 
TABLE 4: ANOVA for two-stage non-full rank linear model.

\begin{tabular}{lcccc}
\hline Source of variation & DF & SS & MS & $F$-cal. \\
\hline Regression & 40 & $544,758,927.5$ & $13,618,973.19$ & $P$ value \\
Error & 960 & $165,231,246.7$ & $172,115.882$ & 79.1267 \\
Total & 1000 & $709,990,174.2$ & & $0.0000^{* *}$ \\
\hline
\end{tabular}

SS = sum of squares and MS = mean sum of squares.

${ }^{* *}$ identify significance at $5 \%$ level of significance.

TABLE 5: ANOVA for tests of significance of continental and item effects.

\begin{tabular}{|c|c|c|c|c|c|}
\hline Source of variation & DF & SS & MS & $F$-cal & $P$ value \\
\hline SSR & 40 & $544,758,927.5$ & $13,618,973.19$ & 79.1267 & $0.0000^{* *}$ \\
\hline$R(\mu)$ & 1 & $58,576,807.34$ & $58,576,807.34$ & 340.3335 & $0.0000^{* *}$ \\
\hline$R(\beta, \alpha: \mu)$ & 39 & $486,182,120.18$ & 12466208.21 & 72.4292 & $0.0000^{* *}$ \\
\hline$R(\alpha, \mu)$ & 5 & $203,512,639.4$ & $40,702,527.89$ & 236.4833 & $0.0000^{* *}$ \\
\hline$R(\alpha: \mu)$ & 4 & $144,935,832.1$ & $36,233,958.02$ & 210.5207 & $0.0000^{* *}$ \\
\hline$R(\beta: \alpha, \mu)$ & 35 & $165,231,246.7$ & $9,749,893.95$ & 56.65 & $0.0000^{* *}$ \\
\hline SSE & 960 & $165,231,246.7$ & $172,115.882$ & & \\
\hline SST & 1000 & $709,990,174.2$ & & & \\
\hline
\end{tabular}

See Tables 1-3 for abbreviations in Table 4.

sector can exist without considering the impact of destination continent. Moreover, the items of export have different contribution to the Norwegian export sector within/or across the destination continent. Fourth, the continental effects (adjusted for the mean $R(\alpha: \mu)$ and without adjusting for the mean $R(\alpha, \mu))$ are statistically significant. The implication is that at least one of the continents does have a significant influence over the others. This is an indicator suggesting that the Norwegian export trade is heterogeneous trade with respect to the amount of revenue generated.

4.2. Econometric Assessment of the Influential Export Items of Norway across Continents. After determining the results from Table 4, we proceed to identify the most and the least influential continents that affect the export trade of Norway with respect to the export items. The general frame of hypotheses is set as follows:

$H_{0}$ : the export of the $j$ th item to the $i$ th continent has no significant impact on the overall performance of the Norwegian export trade, $i=1,2,3,4,5$ and $j=$ $1,2, \ldots, 8$.

$H_{1}: H_{0}$ is not true.

Estimates of the estimable function of the two-stage hierarchical non-full rank model show that $96.67 \%$ of the export trade sector of Norway can be quantified. The significant results are presented in Table 5. Table 5 and column 3 show that the significant items of export explain $96.67 \%$ (9666.79/9681.04) of the export trade of Norway across continents. Only the rest, that is, $322.58 / 9681.04=3.33 \%$, of the export trade of the country are identified from insignificant export items across continents.

From Table 5, we get the following information about the overall continental trade pattern of Norwegian export. First, the significant items of the export trade of Norway are the exports excluding ships and oil platforms (48.7\%), exports of crude oil (19\%), mainland exports (21.2\%), and natural gas (7.9\%). Second, the continents that affect the export trade of Norway significantly (main trade continents) are by most Europe (81.5\%), North and Central America (9.4\%), and Asia and Oceania (5.8\%). Norway seems very dependent on European trade numbers.

4.3. Assessment of Structural Change in the Export Trade of Norway. In the theory of international trade the concept of structural change and trade dynamics are the vital issues. In literature, we can find a number of factors that cause structural changes on the export trade of a given country. However, the factors can be categorized into internal and external causes. With such concepts in mind, we assess the structural changes in the export trade of Norway. Applying a double phase bootstrapping technique on the available data makes the analysis appropriate. Furthermore, the sampling method is appropriate for interpretation. The result of assessment of structural shift is given in Table 6. From the table we can extract the following information. First, the mean squared error (MSE) decreases as we analyse the export trade of Norway by omitting observations from the very past. This is a primary indicator that there exists at least one important structural change on the Norwegian export sector. The most appropriate model is the one having the smallest MSE (export since 2008). The minimization of the MSE of the model indicates that the export trade of Norway much stabilized in these recent times. Second, from 1988 to 2008, the export excluding ships and oil platforms to North and Central America exceeds export of the item to Asia and Oceania. However, since 2008 this item export shows a structural shift in the reverse way. This is an important indicator at the global level showing the economic influence of Asia/China and the economic decline of North America/USA. For Norway, such 
TABLE 6: Test results for the significance of export items across continents.

\begin{tabular}{|c|c|c|c|c|c|c|c|}
\hline Items of export & $\begin{array}{l}\text { Continents as a } \\
\text { source of variations }\end{array}$ & $\begin{array}{l}\text { Estimates of the mean } \\
\text { revenue of export } \\
\text { (in } 100 \text { million NOK) }\end{array}$ & Percent & SS & DF & F-cal. & $P$ value \\
\hline Exports excluding ships and oil platforms & Europe & $3,962.7832$ & $40,9 \%$ & 392591267.30 & 1 & 2280.971 & $0.0000^{* *}$ \\
\hline Export of crude oil & Europe & $1,597.5548$ & $16,5 \%$ & 63804533.48 & 1 & 370.7068 & $0.0000^{* *}$ \\
\hline Mainland exports & Europe & $1,576.5836$ & $16,3 \%$ & 62140396.19 & 1 & 361.0381 & $0.0000^{* *}$ \\
\hline Exports of natural gas & Europe & 756.0592 & $7,8 \%$ & 14290637.85 & 1 & 83.02916 & $0.0000^{* *}$ \\
\hline Exports excluding ships and oil platforms & $\begin{array}{c}\text { North and Central } \\
\text { America }\end{array}$ & 461.8204 & $4,8 \%$ & 5331952.046 & 1 & 30.97885 & $0.0000^{* *}$ \\
\hline Exports excluding ships and oil platforms & Asia and Oceania & 291.9096 & $3,0 \%$ & 2130280.364 & 1 & 12.37701 & $0.0005^{* *}$ \\
\hline Mainland exports & Asia and Oceania & 266.1204 & $2,7 \%$ & 1770501.682 & 1 & 10.28668 & $0.0014^{* *}$ \\
\hline Export of crude oil & $\begin{array}{l}\text { North and Central } \\
\text { America }\end{array}$ & 240.5332 & $2,5 \%$ & 1446405.508 & 1 & 8.403673 & $0.0038^{* *}$ \\
\hline Mainland exports & $\begin{array}{c}\text { North and Central } \\
\text { America }\end{array}$ & 205.1112 & $2,1 \%$ & 1051765.109 & 1 & 6.110796 & $0.0136^{*}$ \\
\hline Rest of exports & Across continents & 322.5828 & $3,3 \%$ & 201188.038 & 31 & 0.037707 & 0.99999 \\
\hline
\end{tabular}

See Table 3 for abbreviations in Table 5.

a trade shift is the key point to mobilize research about the long run consequence of the growth of countries in Asia like China and India. Third, from 1988 to 2002 the export of crude oil to North and Central America exceeded mainland exports. From 2003, the export pattern seems to show structural shift in the reverse way; the mainland exports dominate the exports of crude oil to North and Central America.

4.4. Intracontinental Comparison of Export Items Based on Generated Revenue. The ranking of export items to the destination continents by monetary value is shown in Table 7 . We report the results for the various export items over continents and give a comment below on significant export items. For all continents, exports excluding ships and oil platforms rank number one and are stable. The same item is also expected to be number one in the future. The contribution in the short run is significant for Asia and Oceania, Europe, and North and Central America. For Africa and South America, the short run contribution is insignificant. For the long run contribution, interestingly Africa, Asia and Oceania, Europe, and South America show a growth over time. Europe shows some random effects and high variability. Interestingly, also indicated by Figure 1, North and Central America show no correlation with time and the export item shows considerable variability.

The mainland export item is ranked second for all continents except Europe where the item is ranked number three. For all continents, the rank of the items is stable and the expected rank is unchanged except for North and Central America where the item rank is in the range from two to three. The revenue contribution in the short run is significant for all continents except Africa and South America. The long run contribution is positive and growing with time. However, for Europe the item shows some random variation and North and Central America show considerable variability.
The export of crude oil (natural gas) is ranked second (fourth) for the European continent and ranked third (seven) for North and Central America and Asia and Oceania. For the other two continents, the export of both crude oil and natural gas has low rank and seems insignificant for both short and long run. Importantly for crude oil, Europe and Asia and Oceania report a growth with time while North and Central America show no correlation with time.

4.5. Intercontinental Export Analysis of Significantly Important Items to Different Continents. Across all the destination continents, the significant items of export from Norway across different continents are mainland exports, exports excluding ships and oil platforms, and export of crude oil (Table 9). Our interest is to compare the most and least important continents of these items for Norway. In all cases, the null hypothesis is that there is no difference in the revenue obtained from the export item across continents. Table 8 compares significant export items across continents. Firstly, as before, we see that the European continent is the leading importer from Norway. Secondly, the table shows that the ranking of the leading importers of mainland exports of Norway in descending order is Europe, Asia and Oceania, and North and Central America. The ranking of the leading importers of exports, excluding ships and oil platforms, is also Europe. However, for this export item, the ranking of Asia and Oceania and North and Central America is the same over all subperiods. Finally, for the whole period, the major importer of exports of crude oil is Europe.

\section{Policy Implications}

The results from the analysis of the two-stage hierarchical econometric model show some important implications. Firstly, Europe is Norway's main trading partner in the world. For stable and significant trade numbers Europe counts 
TABLE 7: Structural change analysis.

\begin{tabular}{|c|c|c|c|c|c|c|}
\hline Items of export & $\begin{array}{c}\text { Continents as a } \\
\text { source of variations }\end{array}$ & $\begin{array}{l}\text { Estimates of the mean } \\
\text { revenue of export } \\
\text { (in } 100 \text { million NOK) }\end{array}$ & SS & DF & F-cal. & $P$ value \\
\hline \multicolumn{7}{|c|}{ Export since $1993, F(40,760)=120.02, P$ value $=0.0000^{* *}, \mathrm{MSE}=153258.57$} \\
\hline Exports excluding ships and oil platforms & Europe & $4,555.568$ & 415063996.05 & 1 & 2708.260 & $0.0000^{* *}$ \\
\hline Export of crude oil & Europe & $1,850.750$ & 68505474.24 & 1 & 446.993 & $0.0000^{* *}$ \\
\hline Mainland exports & Europe & $1,755.907$ & 61664152.73 & 1 & 402.354 & $0.0000^{* *}$ \\
\hline Exports of natural gas & Europe & 908.180 & 16495818.25 & 1 & 107.634 & $0.0000^{* *}$ \\
\hline Exports excluding ships and oil platforms & $\begin{array}{c}\text { North and Central } \\
\text { America }\end{array}$ & 537.207 & 5771816.47 & 1 & 37.661 & $0.0000^{* *}$ \\
\hline Exports excluding ships and oil platforms & Asia and Oceania & 341.293 & 2329611.41 & 1 & 15.201 & $0.0001^{* *}$ \\
\hline Mainland exports & Asia and Oceania & 310.369 & 1926578.32 & 1 & 12.571 & $0.0004^{* *}$ \\
\hline Export of crude oil & $\begin{array}{c}\text { North and Central } \\
\text { America }\end{array}$ & 282.872 & 1600325.71 & 1 & 10.442 & $0.0012^{* *}$ \\
\hline Mainland exports & $\begin{array}{c}\text { North and Central } \\
\text { America }\end{array}$ & 234.115 & 1096196.67 & 1 & 7.153 & $0.0076^{* *}$ \\
\hline \multicolumn{7}{|c|}{ Export since $1998, F(40,560)=93.74, P$ value $=0.0000^{* *}, \mathrm{MSE}=122481.48$} \\
\hline Exports excluding ships and oil platforms & Europe & $5,334.832$ & 426906487 & 1 & 3485.478 & $0.0000^{* *}$ \\
\hline Export of crude oil & Europe & $2,163.410$ & 70205142.42 & 1 & 573.190 & $0.0000^{* *}$ \\
\hline Mainland exports & Europe & $1,968.007$ & 58095871.68 & 1 & 474.324 & $0.0000^{* *}$ \\
\hline Exports of natural gas & Europe & $1,149.104$ & 19806600.04 & 1 & 161.711 & $0.0000^{* *}$ \\
\hline Exports excluding ships and oil platforms & $\begin{array}{c}\text { North and Central } \\
\text { America }\end{array}$ & 618.592 & 5739840.937 & 1 & 46.863 & $0.0000^{* *}$ \\
\hline Exports excluding ships and oil platforms & Asia and Oceania & 401.955 & 2423521.35 & 1 & 19.787 & $0.0000^{* *}$ \\
\hline Mainland exports & Asia and Oceania & 365.591 & 2004855.345 & 1 & 16.369 & $0.0001^{* *}$ \\
\hline Export of crude oil & $\begin{array}{c}\text { North and Central } \\
\text { America }\end{array}$ & 318.689 & 1523436.994 & 1 & 12.438 & $0.0005^{* *}$ \\
\hline Mainland exports & $\begin{array}{c}\text { North and Central } \\
\text { America }\end{array}$ & 272.943 & 1117470.948 & 1 & 9.124 & $0.0026^{* *}$ \\
\hline \multicolumn{7}{|c|}{ Export since $2003, F(40,360)=194.56, P$ value $=0.0000^{* *}, \mathrm{MSE}=69362.00$} \\
\hline Exports excluding ships and oil platforms & Europe & $6,286.029$ & 395141605.89 & 1 & 5696.819 & $0.0000^{* *}$ \\
\hline Export of crude oil & Europe & $2,525.006$ & 63756553.00 & 1 & 919.188 & $0.0000^{* *}$ \\
\hline Mainland exports & Europe & $2,187.517$ & 47852306 & 1 & 689.894 & $0.0000^{* *}$ \\
\hline Exports of natural gas & Europe & $1,502.671$ & 22580201 & 1 & 325.542 & $0.0000^{* *}$ \\
\hline Exports excluding ships and oil platforms & $\begin{array}{c}\text { North and Central } \\
\text { America }\end{array}$ & 649.428 & 4217567 & 1 & 60.805 & $0.0000^{* *}$ \\
\hline Exports excluding ships and oil platforms & Asia and Oceania & 473.716 & 2244068 & 1 & 32.353 & $0.0000^{* *}$ \\
\hline Mainland exports & Asia and Oceania & 439.542 & 1931972 & 1 & 27.853 & $0.0000^{* *}$ \\
\hline Mainland exports & $\begin{array}{c}\text { North and Central } \\
\text { America }\end{array}$ & 311.067 & 967626.8 & 1 & 13.950 & $0.0002^{* *}$ \\
\hline Export of crude oil & $\begin{array}{c}\text { North and Central } \\
\text { America }\end{array}$ & 302.299 & 913846.9 & 1 & 13.175 & $0.0003^{* *}$ \\
\hline \multicolumn{7}{|c|}{ Export since 2008, $F(40,160)=284.74 P$ value $=0.0000^{* *}, \mathrm{MSE}=30759.70$} \\
\hline Exports excluding ships and oil platforms & Europe & $7,182.530$ & 257943686.00 & 1 & 8385.767 & $0.0000^{* *}$ \\
\hline Export of crude oil & Europe & $2,768.798$ & 38331211.82 & 1 & 1246.15 & $0.0000^{* *}$ \\
\hline Mainland exports & Europe & $2,384.118$ & 28420093.19 & 1 & 923.9392 & $0.0000^{* *}$ \\
\hline Exports of natural gas & Europe & $1,963.520$ & 19277053.95 & 1 & 626.6984 & $0.0000^{* *}$ \\
\hline Exports excluding ships and oil platforms & Asia and Oceania & 614.126 & 1885754.71 & 1 & 61.30598 & $0.0000^{* *}$ \\
\hline Exports excluding ships and oil platforms & $\begin{array}{c}\text { North and Central } \\
\text { America }\end{array}$ & 605.710 & 1834423.02 & 1 & 59.63722 & $0.0000^{* *}$ \\
\hline Mainland exports & Asia and Oceania & 572.446 & 1638472.12 & 1 & 53.26684 & $0.0000^{* *}$ \\
\hline Mainland exports & $\begin{array}{c}\text { North and Central } \\
\text { America }\end{array}$ & 350.012 & 612542.00 & 1 & 19.91378 & $0.0000^{* *}$ \\
\hline Export of crude oil & $\begin{array}{c}\text { North and Central } \\
\text { America }\end{array}$ & 229.836 & 264122.93 & 1 & 8.586655 & $0.0038^{* *}$ \\
\hline
\end{tabular}

See Table 3 for abbreviations in Table 5. 


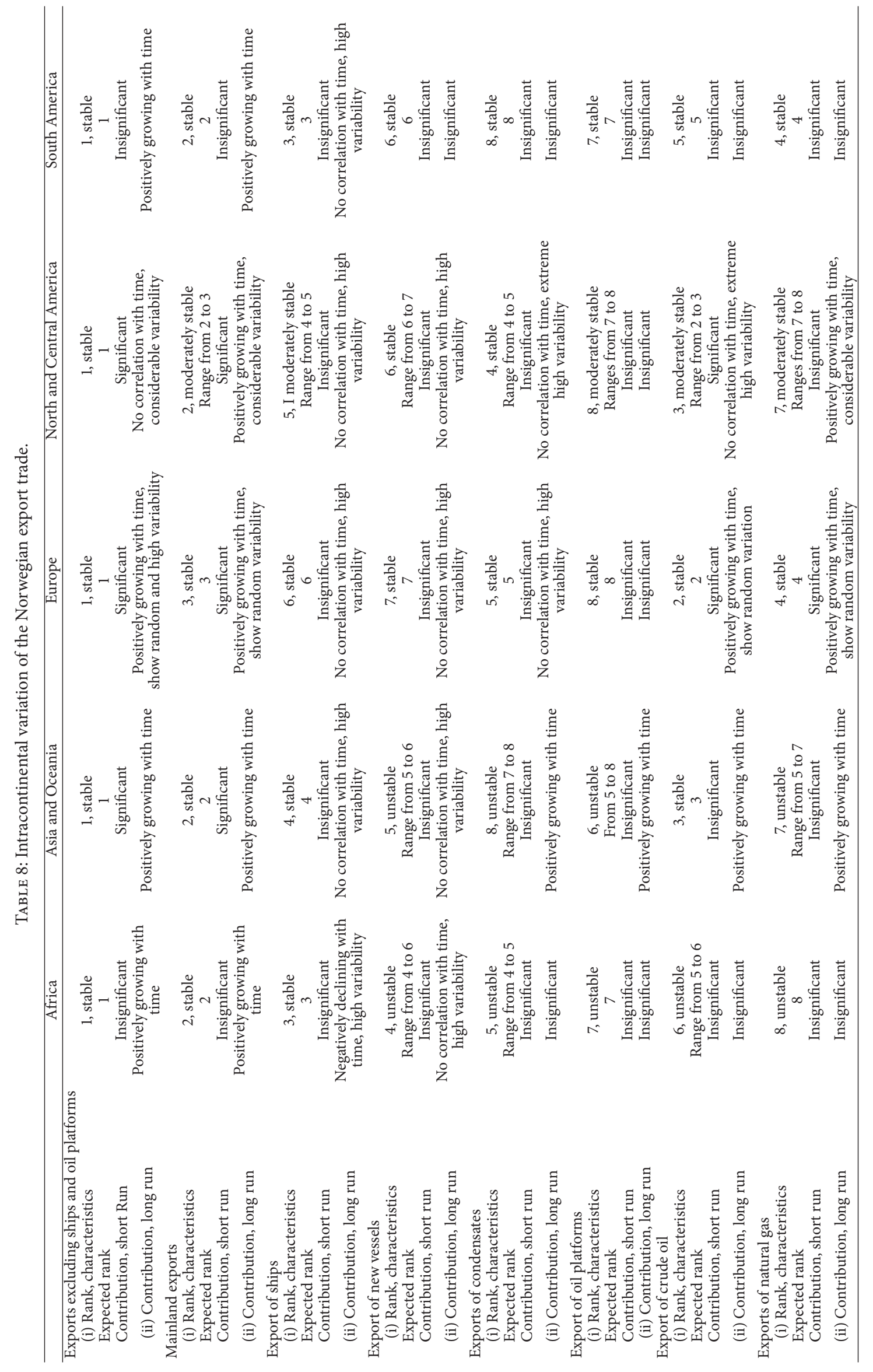


TABLE 9: Multiple comparisons of significant items for Norwegian export across continents.

\begin{tabular}{|c|c|c|c|c|c|}
\hline Item of export & $\begin{array}{l}\text { Comparison of the effect of export } \\
\text { items to continent } i \text { and to } \\
\text { continent } i^{\prime}\end{array}$ & $\begin{array}{l}\text { Net expected difference } \\
\text { (in } 100 \text { million NOK) }\end{array}$ & $\mathrm{DF}$ & $F$-cal. & Significance \\
\hline Mainland exports & Europe versus Asia and Oceania & 1811.672 & 2 & 533.515 & $0.0000^{* *}$ \\
\hline Mainland exports & $\begin{array}{l}\text { Asia and Oceania versus North and } \\
\text { Central America }\end{array}$ & 222.434 & 2 & 8.042485 & $0.0005^{* *}$ \\
\hline Mainland exports & $\begin{array}{l}\text { Europe versus North and Central } \\
\text { America }\end{array}$ & 2034.106 & 2 & 672.5662 & $0.0000^{* *}$ \\
\hline Exports excluding ships and oil platforms & Europe versus Asia and Oceania & 6568.404 & 2 & 7013.061 & $0.0000^{* *}$ \\
\hline Exports excluding ships and oil platforms & $\begin{array}{l}\text { Asia and Oceania versus North and } \\
\text { Central America }\end{array}$ & 8.416 & 2 & 0.011513 & 0.9885 \\
\hline Exports excluding ships and oil platforms & $\begin{array}{c}\text { Europe versus North and Central } \\
\text { America }\end{array}$ & 6576.82 & 2 & 7031.044 & $0.0000^{* *}$ \\
\hline
\end{tabular}

${ }^{* *}$ identify significance at $5 \%$ level of significance.

for $81.5 \%$ of total export. The analysis shows that North and Central America follow Europe with 9.4\%, Asia, and Oceania with $7.8 \%$. For the Norwegian export industry, the European continent seems extremely important. Moreover, the export is stable over time and is consequently expected to be important in the future. Any trade policy of Norway must therefore acknowledge Europe as a considerable contributor to Norwegian welfare, employment, and economic growth.

Secondly, for the period 1988-2012 there has been a revenue shift in trade from North and Central America to Asia and Oceania. The emerging economies in Asia increase their import from Norway while North and Central America show a stagnant Norwegian import. The fact that Asia and Oceania have now emerged as the second largest importer continent of goods from Norway suggests a need for an increased focus on Asia and Oceania for the establishment of stable and reliable trade relations. Moreover, the importance of trade zones is shifted from North and Central America to Asia and Oceania.

Thirdly, the emerging economies have increased their export share from a mean revenue from approximately 650 million NOK in the period 1993-1997 to 765 million in 19982003, 910 million in 2003 to 2008, and nearly 1200 million NOK for the period 2008-2012. This 85\% increase in Asia and Oceania must be compared to the almost stagnation of exports to North and Central America (12.5\%). The stagnation is also clearly visible from the rank characteristics in Table 7.

Fourthly, for Norwegian mainland export, Asia and Oceania clearly outperform North and Central America. The importance of Asia and Oceania of mainland exports finds the continent as one of the main drivers for mainland export, increasing their importance. The finding therefore also indicates a need for policy attention to the relationship with Asia and Oceania for Norway's welfare and growth in the future.

Fifthly, for export of crude oil alone (accounting for $49 \%$ of Norwegian exports), Europe is the most important continent. Moreover, Asia and Oceania also show a significant growth while North and Central America show no correlation with time and extreme variability. For Norwegian policy makers, market access and mutual trade confidence already in place in Europe may be an important factor for Asia and Oceania in the near future.

Finally, the Norwegian authorities have a role to play in reducing variable trade and transportation costs, particularly tariffs, and reducing market entry costs, market failure in the provision of market access and information, and cultural dissimilarities. Smeets et al. [60] suggest that, especially for firms exporting from a small and open economy, establishing new trade relationships could have a significantly larger impact on aggregate trade than intensifying existing ones. They argue that traditional trade policies aimed at lowering tariffs and nontariff barriers are less effective in helping these new trade relationships to develop. Instead, other instruments such as trade missions, bilateral negotiations, and economic diplomacy may have a larger impact in unlocking new export markets. In their words: "This is not only a matter of establishing business networks and infrastructure for doing business; it also entails pressing for institutional and regulatory reforms...”. Furthermore, a policy implication follows on from the fact that only the most productive firms will choose to export to a wide range of markets. If market entry costs are reduced, slightly less productive firms will be able to enter the export market, but still the least productive firms will not export. There is therefore little need to pick winners; they will select themselves.

\section{Summary and Conclusions}

This paper has applied the two-stage hierarchical non-full rank linear econometric model to analyse export trade of Norway across five continents. The model is linear, having two independent factors in which one of the factors is nested in the other factor. Specifically, the dependent variable export trade of Norway is regressed against the two independent variables where export items are nested within export continents.

The estimation results show important implications for Norwegian export. First, the European continent dominates all other continents over all export items. Second, there has been a shift from North and Central America to Asia 
and Oceania for mainland exports. The results suggest importance of policy implications for Norwegian authorities and emphasis on new and improved free trade zones for Norwegian mainland merchandises.

Finally, while the modelling technique is challenging, the results are interesting and contain important policy implications. For Norwegian authorities, all actions reducing variable trading and transport costs for the growing, stable, and important trading partners will increase the number of Norwegian firms that are able to export, supporting the growth and welfare for Norwegian citizens.

\section{Conflict of Interests}

The authors declare that there is no conflict of interests regarding the publication of this paper.

\section{Acknowledgments}

First and foremost, the authors give ultimate thanks for their creator God who gave them space to live and time to think. Second, they would like to thank the scholars referenced in the paper. Finally, they would like to thank all the members of Molde University College.

\section{References}

[1] L. W. McKenzie, "Specialisation and efficiency in world production," The Review of Economic Studies, vol. 21, no. 3, pp. 165-180, 1954.

[2] J. S. Chipman, "A survey of the theory of international trade: part 1, the classical theory," Econometrica, vol. 33, no. 3, section 1.8, pp. 477-519, 1965.

[3] I. Steedman, Fundamental Issues in Trade Theory, MacMillan, London, UK; St. Martin's Press, New York, NY, USA, 1979.

[4] I. Steedman, Trade Amongst Growing Economies, Cambridge University Press, Cambridge, UK, 1979.

[5] G. J. Felbermayr and W. Kohler, "Exploring the intensive and extensive margins of world trade," Review of World Economics, vol. 142, no. 4, pp. 642-674, 2006.

[6] P. R. Krugman, M. Obstfeld, and M. J. Melitz, International Economics, 2012.

[7] A. V. Deardorff, "Determinants of bilateral trade: does gravity work in a neoclassical world?" in The Regionalization of the World Economy, J. A. Frankel, Ed., University of Chicago Press, Chicago, Ill, USA, 1998.

[8] J. H. Bergstrand, "The gravity equation in international trade: some microeconomic foundations and empirical evidence," The Review of Economics and Statistics, vol. 67, no. 3, pp. 474-481, 1985.

[9] M. Mele and P. A. Baistrocchi, "A critique of the gravitational model in estimating the determinants of trade flows," International Journal of Business and Commerce, vol. 2, no. 1, pp. 13-23, 2012.

[10] R. R. Huang, "Distance and trade: disentangling unfamiliarity effects and transport cost effects," European Economic Review, vol. 51, no. 1, pp. 161-181, 2007.

[11] S. L. Baier and J. H. Bergstrand, "The growth of world trade: tariffs, transport costs, and income similarity," Journal of International Economics, vol. 53, no. 1, pp. 1-27, 2001.
[12] J. E. Anderson, "A theoretical foundation for the gravity equation," The American Economic Review, vol. 69, pp. 106-116, 1979.

[13] C. Evans, National Border Effects, Heterogeneous Fixed Costs of International Trade, and Variety Availability, Mimeo, 2000.

[14] P. E. Jensen, "Analysis of bilateral trade patterns with panel data," Review of International Economics, vol. 8, no. 1, pp. 86-99, 2000.

[15] A. Porojan, "Trade flows and spatial effects: the gravity model revisited," University of Derby Working Paper, University of Derby, Derby, UK, 2000.

[16] UNDP, Trade and Environment Review, UNDP, 2013, http:// unctad.org/en/publicationslibrary/ditcted2012d3_en.pdf.

[17] P. S. Mann, Introductory Statistics, Wiley, 2nd edition, 1995.

[18] N. Gershenfeld, The Nature of Mathematical Modeling, Cambridge University Press, New York, NY, USA, 1999.

[19] M. D. Bordo and B. Eichengreen, A Retrospective on the Bretton Woods System: Lessons for International Monetary Reform, 1993.

[20] P. Perron, The Great Crash, the Oil Price Shock and the Unit Root Hypothesis, Econometric Research Program, Princeton University, Princeton, NJ, USA, 1988.

[21] D. E. Philip, "Comparing bear markets-1973 and 2000," National Institute Economic Review, vol. 183, no. 1, pp. 78-89, 2003.

[22] M. Seltzer, J. Novak, K. Choi, and N. Lim, "Sensitivity analysis for hierarchical models employing t level-1 assumptions," Journal of Educational and Behavioral Statistics, vol. 27, no. 2, pp. 181-222, 2002.

[23] D. Draper, "Inference and hierarchical modeling in the social sciences," Journal of Educational and Behavioral Statistics, vol. 20, no. 2, pp. 115-147, 1995.

[24] H. Goldstein, "Multilevel mixed linear model analysis using iterative generalized least squares," Biometrika, vol. 73, no. 1, pp. 43-56, 1986.

[25] F. G. Giesbrecht and J. C. Burns, "Two-stage analysis based on a mixed model: large-sample asymptotic theory and smallsample simulation results," Biometrics, vol. 41, no. 2, pp. 477486, 1985.

[26] A. S. Bryk and S. W. Raudenbush, Hierarchical Linear Models: Applications and Data Analysis Methods, Sage, Newbury Park, Calif, USA, 1992.

[27] H. Thompson, International Economics: Global Markets and Competition, World Scientific-Penerbit, 3rd edition, 2011.

[28] C. Smith, International Trade and Globalisation, Anforme, Stocksfield, UK, 3rd edition, 2007.

[29] G. M. Grossman and E. Helpman, Innovation and Growth in the Global Economy, MIT Press, Cambridge, Mass, USA, 1991.

[30] T. L. Friedman, The Lexus and the Olive Tree: Understanding Globalization, Anchor Books, New York, NY, USA, 1st edition, 2000.

[31] D. Brady, Comparing European Workers: Policies and Institutions, Emerald Group Publishing, 2011.

[32] E. Guido and M. Vermeire, Macroeconomics and Beyond: Essays in Honour of Wim Meeusen, Maklu, 2012.

[33] S. Babones, "Studying globalization: methodological issues," in The Blackwell Companion to Globalization, G. Ritzer, Ed., pp. 147-149, John Wiley \& Sons, New York, NY, USA, 2008.

[34] M. Steger, Globalization: A Very Short Introduction, Oxford University Press, New York, NY, USA, 2009.

[35] K. Saggi, "Trade, foreign direct investment, and international technology transfer: a survey," World Bank Research Observer, vol. 17, no. 2, pp. 191-235, 2002. 
[36] S. S. Golub and C.-T. Hsieh, "Classical Ricardian theory of comparative advantage revisited," Review of International Economics, vol. 8, no. 2, pp. 221-234, 2000.

[37] R. C. Feenstra, "The Heckscher-Ohlin model," in Advanced International Trade: Theory and Evidence, Princeton University Press, Princeton, NJ, USA, 2004.

[38] K. Alsos and L. Eldring, "Labour mobility and wage dumping: the case of norway," European Journal of Industrial Relations, vol. 14, no. 4, pp. 441-459, 2008.

[39] OECD, Economic Surveys Norway, 2012, https://www.regjeringen.no/contentassets/00de488748c248fdb07e61c79ac563e1/ overview_landrapporten.pdf.

[40] D. Gonzalez Kilinc, A. Weidmann, and N. Weidmann, "Renewable energy development hydropower in Norway," Seminar Paper In International Finance and Economics, 2011, https://www.th-nuernberg.de/fileadmin/Fachbereiche/bw/ studienschwerpunkte/international_business/Master/CAIFD/ SeminarPapers/HydropowerNorway_SeminarPaper.pdf.

[41] Bureau of Labor Statistics, International Comparisons of GDP per Capita and per Hour, 1960-2010, Division of International Labor Comparisons, 2011.

[42] A. Douglas, Multilevel Modeling, Sage, Thousand Oaks, Calif, USA, 3rd edition, 2004.

[43] I. G. G. Kreft and J. de Leeuw, Introducing Multilevel Modeling, SAGE Publications, London, UK, 1998.

[44] S. R. Searle, Linear Models, John Wiley \& Sons, 1971.

[45] A. Charnes, E. L. Frome, and P. L. Yu, "The equivalence of generalized least squares and maximum likelihood estimates in the exponential family," Journal of the American Statistical Association, vol. 71, no. 353, pp. 169-171, 1976.

[46] C. R. Rao and S. K. Mitra, Generalized Inverse of Matrices and Its Applications, John Wiley \& Sons, New York, NY, USA, 1971.

[47] T. Y. Lam, Lectures on Modules and Rings, vol. 189 of Graduate Texts in Mathematics, Springer, New York, NY, USA, 1999.

[48] O. Bretscher, Linear Algebra with Applications, Prentice Hall, Upper Saddle River, NJ, USA, 3rd edition, 1995.

[49] J. Savoy, "Statistical inference in retrieval effectiveness evaluation," Information Processing and Management, vol. 33, no. 4, pp. 495-512, 1997.

[50] I. T. Jolliffe, "A note on the use of principal components in regression," Journal of the Royal Statistical Society Series C: Applied Statistics, vol. 31, no. 3, pp. 300-303, 1982.

[51] M. K. Simon, Probability Distributions Involving Gaussian Random Variables, Springer, New York, NY, USA, 2002.

[52] A. Mood, F. A. Graybill, and D. C. Boes, Introduction to the Theory of Statistics, McGraw-Hill, 3rd edition, 1974.

[53] R. K. Elswick Jr., C. Gennings, V. M. Chinchilli, and K. S. Dawson, "A simple approach for finding estimable functions in linear models," The American Statistician, vol. 45, no. 1, pp. 5153, 1991.

[54] R. D. Cook and S. Weisberg, Residuals and Influence in Regression, Chapman \& Hall, New York, NY, USA, 1982.

[55] M. S. Bartlett, "Properties of sufficiency and statistical tests," Proceedings of the Royal Statistical Society. Series A, vol. 160, pp. 268-282, 1937.

[56] S. Chatterjee and J. S. Simonoff, Handbook of Regression Analysis, Wiley, New York, NY, USA, 2013.

[57] G. G. Judge, W. E. Griffiths, R. C. Hill, H. Lütkepohl, and T.-C. Lee, The Theory and Practice of Econometrics, Wiley, New York, NY, USA, 2nd edition, 1985.
[58] L. G. Godfrey, "Testing against general autoregressive and moving average error models when the regressors include lagged dependent variables," Econometrica, vol. 46, no. 6, pp. 1293-1302, 1978.

[59] D. Cochrane and G. H. Orcutt, "Application of least squares regression to relationships containing autocorrelated error terms," Journal of the American Statistical Association, vol. 44, no. 245, pp. 32-61, 1949.

[60] R. Smeets, H. Creusen, A. Lejour, and H. Kox, Export Margins and Export Barriers: Uncovering Market Entry Costs of Exporters in the Netherlands, CPB Document No. 208, CPB, The Hague, The Netherlands, 2010, http://works.bepress.com/ henk_kox/23/. 

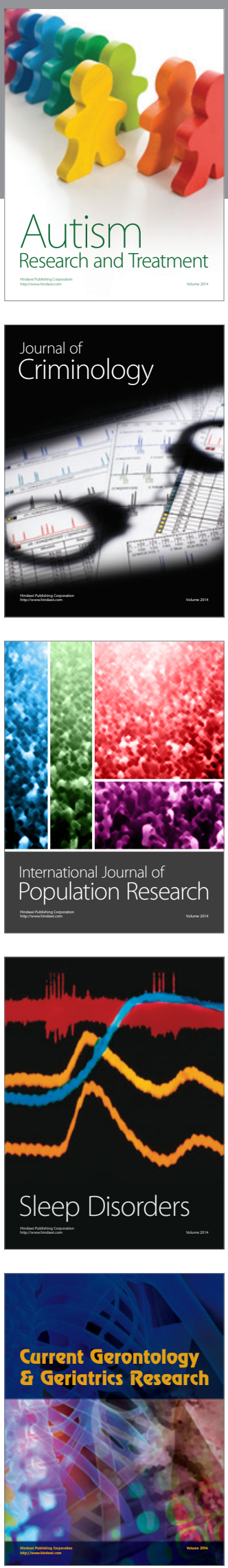
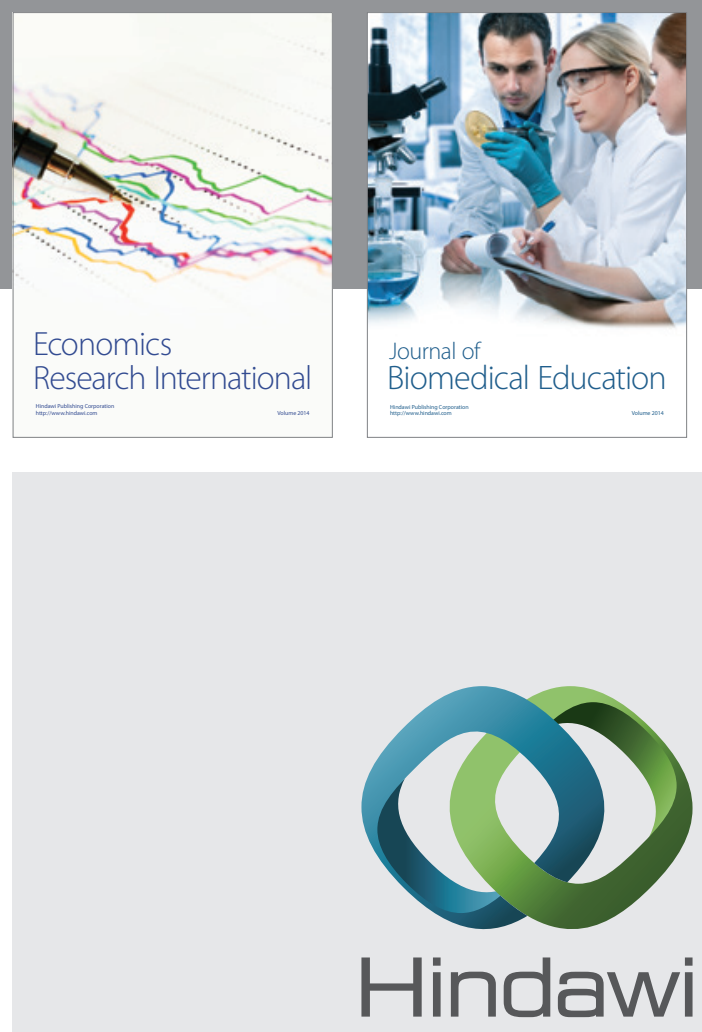

Submit your manuscripts at

http://www.hindawi.com
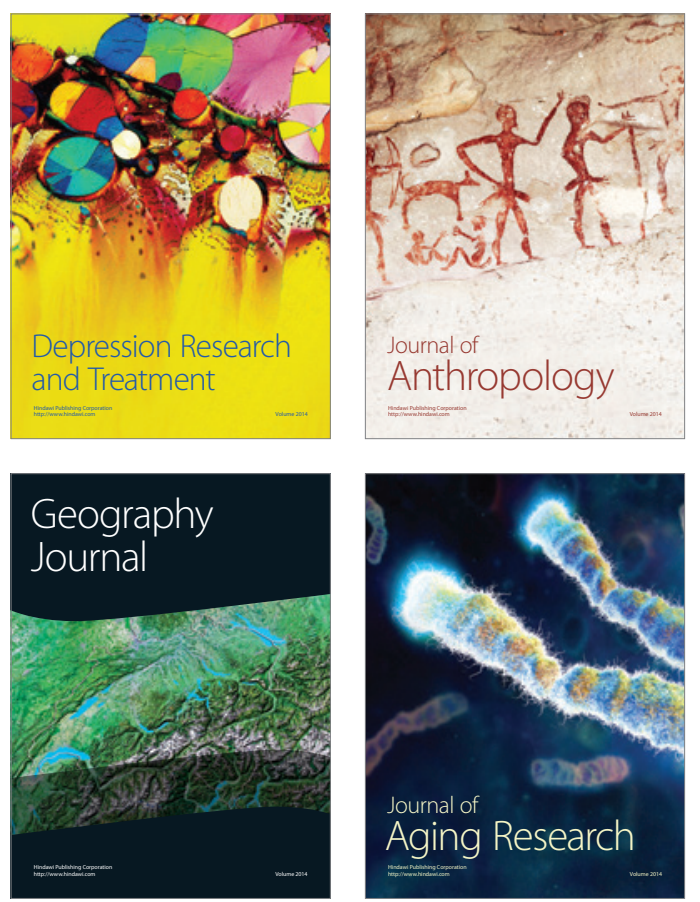
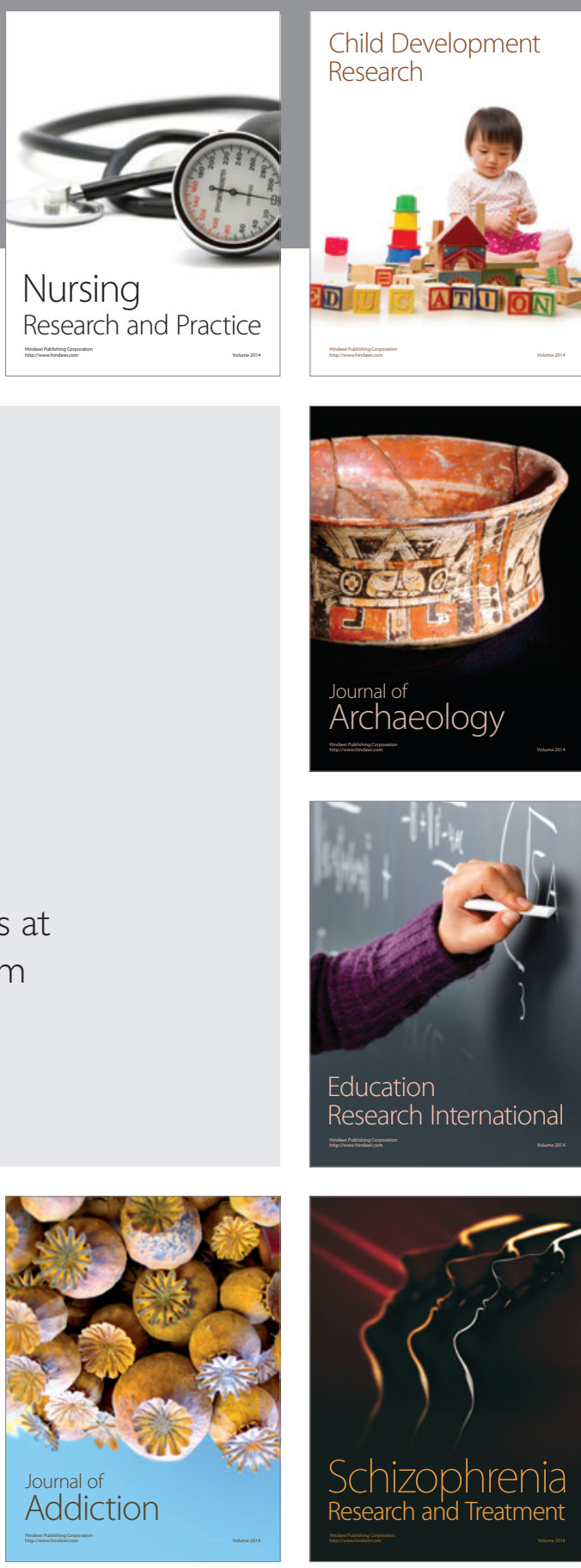

(D)
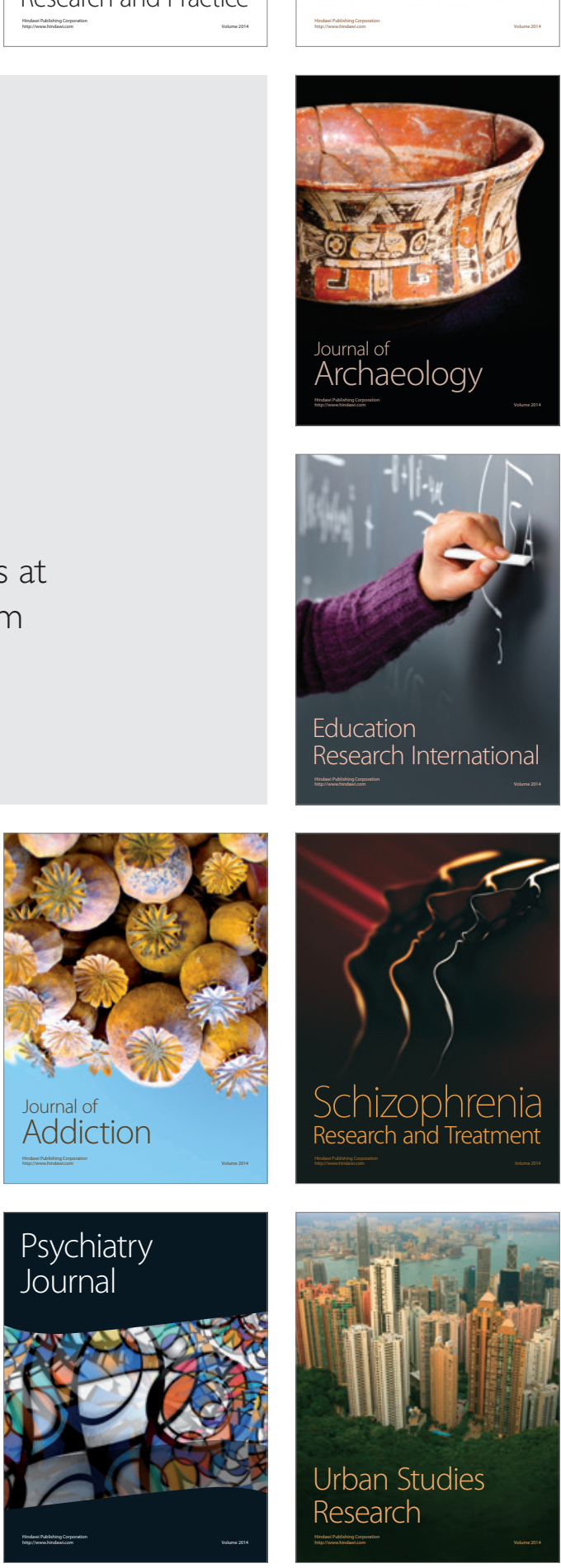